\title{
高電圧印加法を用いた電着涻装鋼板の耐食性評価
}

\author{
浅田照朗 ${ }^{1)}$, 重永 勉 ${ }^{1)}$, 礒本良則 ${ }^{2)}$ * \\ 1) マツダ株式会社 技術研究所 \\ 2) 広島大学大学院工学研究科
}

\section{Evaluation of Corrosion Resistance for Electrodeposition Coating Steel with a High Voltage Supplied Method}

\author{
Teruaki Asada $^{1)}$, Tsutomu Shigenaga ${ }^{1)}$ and Yoshinori Isomoto ${ }^{2) *}$ \\ 1) Mazda Motor Corporation, Technical Research Center \\ 2) Hiroshima University, Graduate School of Engineering
}

\begin{abstract}
*責任著者(Corresponding Author) ７ 739-8527 東広島市鏡山 1-4-1(1-4-1 Kagamiyama, Higashi-hiroshima, 739-8527, Japan) Email: iyoshi@hiroshima-u.ac.jp
\end{abstract}

\begin{abstract}
A new time accelerated testing method of corrosion resistance for electrodeposition coating steel was proposed in this study. This method is to measure a cut off voltage on environmental corrosion factors obtained by linearly increasing voltage of $1 \mathrm{~V} \cdot \mathrm{s}^{-1}$ within a few minute working time, in order to shorten an evaluation span of coating steels. The cut off voltage was measured for the cation electrodeposition coating steels of different coating thickness and different baking conditions after the coating process. As a result, the cut off voltage increased with the increase in thickness and crosslink density of the coating layer. The cut off voltage was well related to the blister initiation cycle number obtained by a cyclic corrosion test. The effectiveness of this method was then recognized. And ion permeability tests and FTIR analyses intimated penetration of ions and adsorption processes into the electrodeposition coating layer.
\end{abstract}

Key words : evaluation of corrosion resistance, electrodeposition coating steel, electro-chemical measurement

\section{1. 緒言}

近年，寒冷地における凍結防止塩の散布量増加 ${ }^{1)}$ や生 産と販売地域のグローバル化にともない, より厳密な防 錆品質の作り込みが必要となっている．塗装鋼板には亜 鉛めっき鋼板や非めっき鋼板があり，その耐食性の違い から用途に応じて使い分けられている。また，鋼板に化 成処理を施した後に，それぞれの機能を向上させるため に下塗り，中塗りそして上塗りがなされる。このうち耐 食性に関わる下塗りの部分が化成処理を含む電着塗装膜 である．以後では化成処理も含めて単に電着塗装膜と表 記する。塗装鋼板の耐食性評価において, 電着塗装膜の 評価は極めて重要である.

電着塗装膜の耐食性試験法として, 自動車の実走行環 境を模擬した複合サイクル試験 ${ }^{2)}$, 塩水噴霧試験 ${ }^{3)}$ など が一般的であるが，各社独自の試験モードをもっている のが現状である。また，これらの試験に要する時間は長 く，数日から長いものでは半年を要する，従って，防錆 品質の造り达みには長期の期間が必要で, 開発期間の短 縮が大きな課題のひとつであった。ささらに日常の品質管 理面においても耐食性試験時間の短縮が強く望まれてい る。これらの耐食性試験の評価指標として, 外観観察に よる発錆面積の測定，膨れ発生度合いの測定 ${ }^{4)}$ がある が，一般には自動計測が難しく品質見本に基づいた目視 による定性評価が主流である。一方，電着塗装膜の電気 化学的な性質を直接測定するインピーダンス測定 ${ }^{5)}$ は定
量性と自動計測の面では有利であるが，電気化学測定装 置が高価であると同時に試験片の準備も煩雑である。ま た，工場などの電磁波ノイズの多い場所では測定が困難 であるといった制約がある。

そこで本研究では, 従来の電着塗装鋼板の耐食性試験 法に比べて汎用性が高く, 迅速試験が可能な耐食性試験 法を提案することおよび，提案した試験法の妥当性を確 かめることを目的とした.

\section{2. 試験装置および試験方法}

\section{1 高電圧印加試験}

高電圧印加試験装置の概略を Fig. 1 に示す. 任意の大 きさの試験片に内径 $10 \sim 12 \mathrm{~mm}$ の接液部(浸漬面積 0.79 $1.13 \mathrm{~cm}^{2}$ ) 有する溶液セルを置き, 試験片と溶液

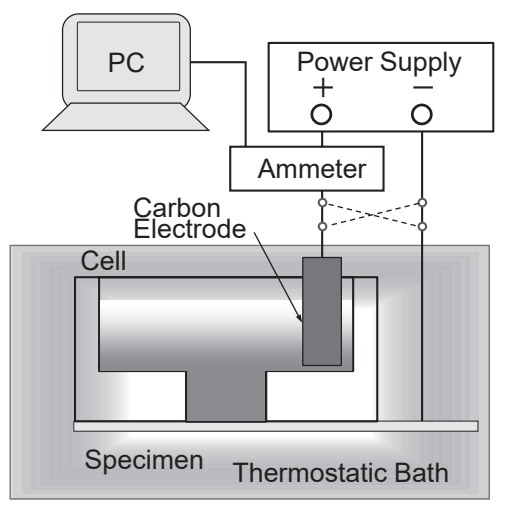

Fig. 1 Schematic illustration of a test cell and a bath. 
セルを固定する．溶液セルの中に炭素棒電極を入れ，電 源を用いて電流計, 炭素棒電極, 試料極を直列に接続し た。試験液には 298〜 353 K の $5 \mathrm{wt} \% \mathrm{NaCl}$ 溶液を用い た. 試験片に電圧を印加し, 掃引速度 $1 \mathrm{~V} \cdot \mathrm{s}^{-1}$ で電圧を 増加させたときに流れる電流を $0.5 \sim 1 \mathrm{~s}$ 間隔で測定し た. 電流值が $10 \mathrm{~mA}$ に達したときに電圧印加を中止し, そのときの電圧を電着塗装膜の腐食因子遮断電圧と定義 した. 以後では単に遮断電圧と表記する. 試験片がア ノードとなるように+(プラス)の電圧を印加した場合の 遮断電圧 (Cut off Voltage) を $\mathrm{CV}(+)$ とし, 試験片がカ ソードになるようにー(マイナス)の電圧を印加した場合 を $\mathrm{CV}(-)$ とした．測定回数は一条件に対して 10 点前後 として, 測定電圧の平均值で示した.

\section{2 複合サイクル試験}

複合サイクル条件では，塩水噴霧 $6 \mathrm{~h}$, 乾燥 $3 \mathrm{~h}$, 湿潤 $14 \mathrm{~h}$, 送風 $1 \mathrm{~h}$ を 1 サイクルとした繰り返しモードで試 験を実施し，電着塗装膜表面に発生した塗膜膨れを目視 で観察した。塗膜膨れが発生するまでの期間を塗膜膨れ 発生サイクル数として表し, 電着塗装膜が腐食を抑制す る期間とみなした。

\section{3 電着塗装膜のイオン透過試験}

電着塗装膜のイオン透過試験セルを Fig. 2 に示す. 鋼 板に施した電着塗装膜とほぼ同一条件で, Snめっき板上 に電着塗装膜厚 $20 \mu \mathrm{m}$ を形成させた後に $423 \mathrm{~K}$ で $20 \mathrm{~min}$ 焼付けを実施した。その後，水銀アマルガム法により電 着塗装膜を取り出し供試材として用いた。容量約 $5 \mathrm{ml}$ の 2 つの溶液セルの中央に直径 $12 \mathrm{~mm}$ 電着塗装膜 (透過面積

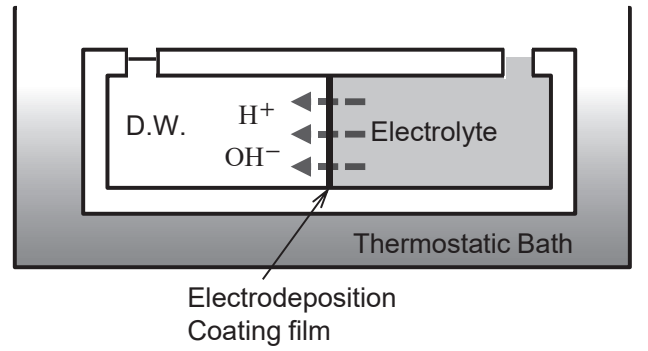

Fig. 2 Schematic illustration of an ion permeability test cell. $\left.1.13 \mathrm{~cm}^{2}\right)$ を O- リングを用いて固定し, 一方に電気伝導度 の異なる電解液として種々の濃度の $\mathrm{HCl}, \mathrm{NaCl}, \mathrm{NaOH}$ 溶液を, 他方にイオン交換水(電気伝導度 $1 \mu \mathrm{S} \cdot \mathrm{cm}^{-1}$ 以下) を入れた. $343 \mathrm{~K}$ の恒温槽に試験セルを入れ，約 $30 \mathrm{~min}$ 後にイオン交換水の電気伝導度の上昇を測定した。 また 試験後の電着塗装膜を目視観察した後にフーリエ変換赤 外分光分析 (FTIR)を行った.

\section{4 試験片}

試験片には電着塗装を施した非めっき鋼板 $(\mathrm{CRS})$ およ び亜鉛めっき鋼板 $(\mathrm{GA})$ を用いた。脱脂後の鋼板にリン 酸亜鉛化成処理 (処理時間 $10,120 \mathrm{~s}$ ) を行い, 電着塗装 膜 (厚さ $6 \sim 16 \mu \mathrm{m}$ ) を施した後, 焼付温度 $413,423 \mathrm{~K}$ と 焼付時間 15, $20 \mathrm{~min}$ の異なる焼付処理を行った. 用い た試験片および処理条件を Table 1 に示した. 化成処理 および焼付処理条件を A〜Dで区別した．ただし，A と B では焼付処理条件は同じで化成処理時間が異なる．化成 処理層, 電着塗装膜厚は浴槽環境や塗装条件に強く依存 するので，浴槽毎に膜厚は異なる。電着塗装後に膜厚計 を用いて電着塗装膜厚を測定した。試験片の表記の一例 として, 非めっき鋼板に化成処理 $120 \mathrm{~s}$, 焼付温度 $423 \mathrm{~K}$, 焼付時間 $20 \mathrm{~min}$, 電着塗装膜厚が $12 \mu \mathrm{m}$ 相当の電着塗 装を施したものを CRS A-12 とした。電着塗装膜の架橋 密度は焼付条件に依存する。架橋密度測定には動的粘弾 性スペクトロメーターを用い, 電着塗装膜樹脂の温度と 粘弾性の関係から架橋密度を求めた. 焼付処理条件 A, C, D における架橋密度はそれぞれ $0.0031 ， 0.00095$ およ び $0.00092 \mathrm{~mol} \cdot \mathrm{cm}^{-3}$ であった，B の架橋密度は求めてい ないがAと同等と考えられる.

非めつき鋼板および亜鉛めっき鋼板の化成処理(処理 時間 $10,120 \mathrm{~s}$ ) 後の SEM 観察を Fig. 3 に示す. 非めっ き鋼板上の化成処理層は, 化成処理時間 $10 \mathrm{~s}$ では粒状の リン酸塩結晶の形成が認められるが，粒子間に隙間が存 在するのに対し，120 s では隙間が無く緻密に結晶が析 出していることが観察された. 一方, 覀鉛めっき鋼板の 化成処理層では $10 \mathrm{~s}$ においても粒状および針状のリン酸 塩結晶が隙間無く析出しており，120 s では更に多くの 結晶が析出していることが観察された. 2 つの鋼板でリ ン酸塩結晶の形成に違いが見られるのは鋼板の表面の組

Table 1 Electrodeposition conditions and cut off voltage of specimens.

\begin{tabular}{cccccccc}
\hline Type & Symbol & $\begin{array}{c}\text { Film } \\
\text { Thickness } \\
(\mu \mathrm{m})\end{array}$ & $\begin{array}{c}\text { Baking } \\
\text { Temp. } \\
(\mathrm{K})\end{array}$ & $\begin{array}{c}\text { Baking } \\
\text { Time } \\
(\mathrm{min})\end{array}$ & $\begin{array}{c}\text { Chemical } \\
\text { Conversion } \\
\text { Time }(\mathrm{s})\end{array}$ & $\begin{array}{c}\text { Cut off } \\
\text { Voltage }(+) \\
(\mathrm{V})\end{array}$ & $\begin{array}{c}\text { Norm. Cut } \\
\text { off Voltage } \\
\left(\mathrm{V} \cdot \mu \mathrm{m}^{-1}\right)\end{array}$ \\
\hline CRS & A-6 & 5.7 & 423 & 20 & 120 & 46 & 8.0 \\
& A-7 & 7.4 & 423 & 20 & 120 & 112 & 15.1 \\
& A-10 & 10.7 & 423 & 20 & 120 & 242 & 22.7 \\
& A-12 & 11.7 & 423 & 20 & 120 & 393 & 33.6 \\
& A-16 & 16.1 & 423 & 20 & 120 & 426 & 26.5 \\
& B-13 & 12.6 & 423 & 20 & 10 & 344 & 27.3 \\
& C-10 & 9.9 & 413 & 20 & 120 & 191 & 19.2 \\
& C-12 & 12.0 & 413 & 20 & 120 & 268 & 22.3 \\
& D-12 & 12.0 & 413 & 15 & 120 & 171 & 14.3 \\
& D-10 & 9.8 & 413 & 15 & 120 & 128 & 13.1 \\
& A-6 & 5.8 & 423 & 20 & 120 & 89 & 15.3 \\
& A-9 & 8.7 & 423 & 20 & 120 & 261 & 30.0 \\
& A-13 & 13.2 & 423 & 20 & 120 & 389 & 29.4 \\
& A-14 & 13.8 & 423 & 20 & 120 & 454 & 32.9 \\
& A-16 & 16.1 & 423 & 20 & 120 & 453 & 27.6 \\
& B-13 & 12.8 & 423 & 20 & 10 & 379 & 28.7 \\
& C-14 & 13.5 & 413 & 20 & 120 & 365 & 27.0 \\
& D-14 & 14.0 & 413 & 15 & 120 & 308 & 22.0 \\
\hline
\end{tabular}


成とそれにともなう表面反応が両者で異なるためと考え られる。

\section{3. 試験結果および考察}

\section{1 高電圧印加試験}

高電圧印加試験の一例として CRS D-12 および GA D-14 の時間 - 電流曲線を Fig. 4 に示す. 掃引速度は $1 \mathrm{~V} \cdot \mathrm{s}^{-1}$ であるので遮断電圧 $(\mathrm{CV}(+))$ と時間の值は一致する. 時間初期には電流はほとんど流れず，遮断電圧に達する 数秒前に電流が流れ出し遮断電圧に達することが分か る. $10 \mathrm{~mA}$ に達したところで電圧印加を中止しても, 電 流は瞬間的に高くなる場合があった。この図から，CRS よりも GA の遮断電圧の方が高いことが分かる．両者の 間で電着塗装膜厚に違いがあるが，単位膜厚当りの遮断 電圧で比較しても GA の遮断電圧の方が高い (Table 1 参 照).

室温, $5 \mathrm{wt} \% \mathrm{NaCl}$ 溶液中において, 化成処理時間, 焼付条件の異なる CRS, GA の電着塗装膜厚に対する遮 断電圧 $(\mathrm{CV}(+))$ を Fig. 5 に示す。この図から, 電着塗装 膜が厚いほど遮断電圧が高くなることが分かった。ま た，電着塗装膜厚が $12 \sim 13 \mu \mathrm{m}$ において化成処理時間が 短い記号 B の遮断電圧は焼付条件が同じ記号 Aのそれ とあまり変わらないことから, 化成処理時間は遮断電圧 にあまり影響を与えないことが分かる. 焼付温度 $413 \mathrm{~K}$,
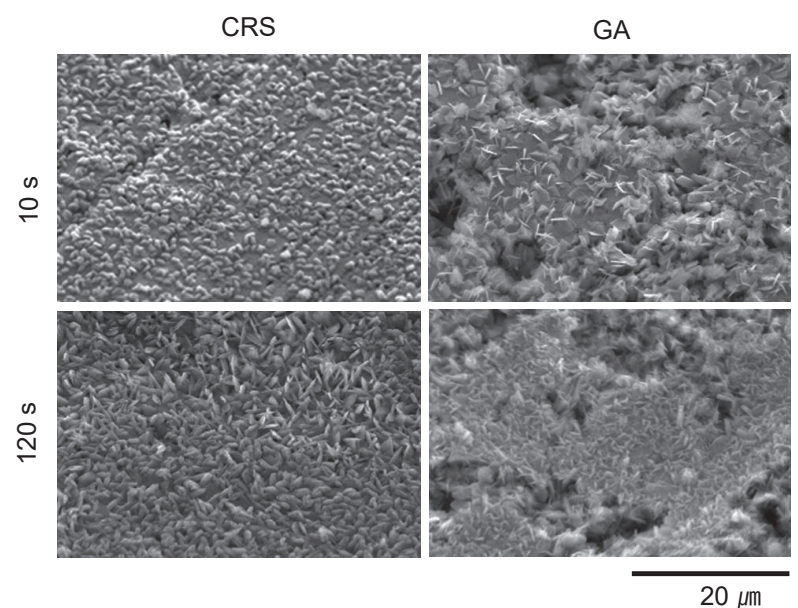

Fig. 3 SEM images of chemical conversion coating surfaces of CRS and GA specimens.

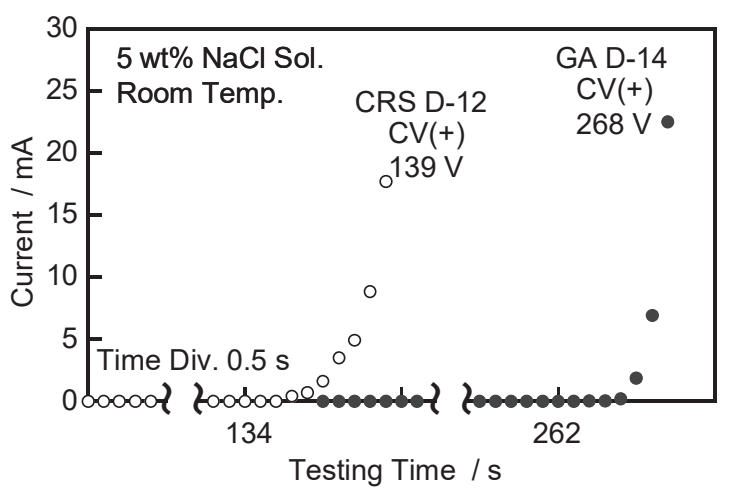

Fig. 4 Current versus testing time curves in a high voltage supplied method.
焼付時間 $20 \min ($ 記号 C) の遮断電圧は焼付温度 $423 \mathrm{~K}$, 焼付時間 $20 \mathrm{~min}($ 記号 $\mathrm{A}$ )よりも僅かに低いように見え る. しかし, 焼付温度 $413 \mathrm{~K}$, 焼付時間 $15 \mathrm{~min}($ 記号 D) の遮断電圧は明らかにそれ以外の焼付条件よりも低い結 果が得られた。電着塗装膜厚が同じであれば GAの遮断 電圧の方が CRSよりも高くなった.

焼付温度 $423 \mathrm{~K}$, 焼付時間 $20 \mathrm{~min}$, 電着塗装膜厚を $12,13 \mu \mathrm{m}$ として, 試験液の温度を変え, 試験片をア ノードあるいはカソードとしたときの CRS, GA の遮断 電圧 $(\mathrm{CV}(+), \mathrm{CV}(-))$ の変化を, $\mathrm{CRS} \mathrm{A}-12$ の遮断電圧 に対する相対值で表した結果を Fig. 6 に示す. CRS, GA ともに試験液の温度が高くなるにつれて遮断電圧は低く なったが, GAの遮断電圧はより低くなった。また, CRS ではアノード, カソードどちらの場合でも, 温度上 昇に対する遮断電圧の低下にそれほど大きな差がなかっ たのに対し，GAではカソードにした方の遮断電圧が大 きく低下した。したがって，温度によって CRS と GAの 耐食性が異なり，温度が高い場合には GAの耐食性は CRSよりも劣ると予想される。この差は電着塗装膜内を 透過するイオンが関わるとして後述する.

\section{2 複合サイクル試験および高電圧印加試験との比較} 電着塗装条件の異なる $\mathrm{CRS}$ および $\mathrm{GA}$ の中から複合サ イクル試験における塗膜膨れ発生サイクル数と遮断電圧 の関係を見たものを Fig. 7 に示す。一般に電着塗装膜厚 の増加に伴って複合サイクル試験における塗膜膨れ発生 サイクル数は増加する. 塗膜膨れ発生サイクル数の増加

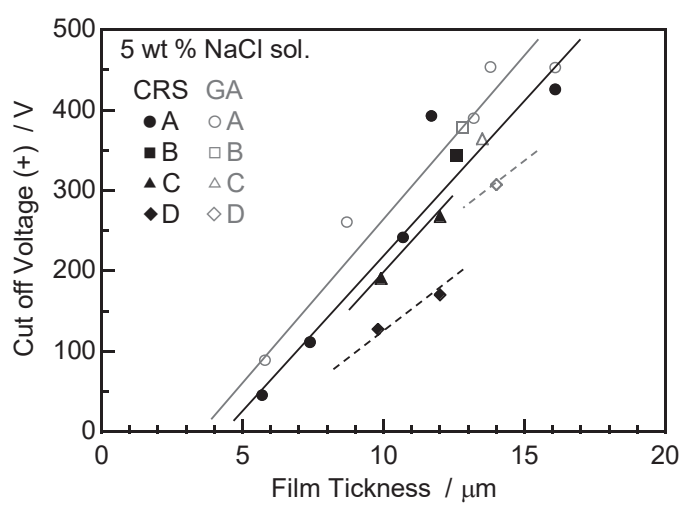

Fig. 5 Effects of electrodeposition condition on cut off voltage ( + ). A : $423 \mathrm{~K}, 20 \mathrm{~min}, 120 \mathrm{~s}, \mathrm{~B}: 423 \mathrm{~K}, 20 \mathrm{~min}, 10 \mathrm{~s}, \mathrm{C}$ : $413 \mathrm{~K}, 20 \mathrm{~min}, 120 \mathrm{~s}$, and D : $413 \mathrm{~K}, 15 \mathrm{~min}, 120 \mathrm{~s}$.

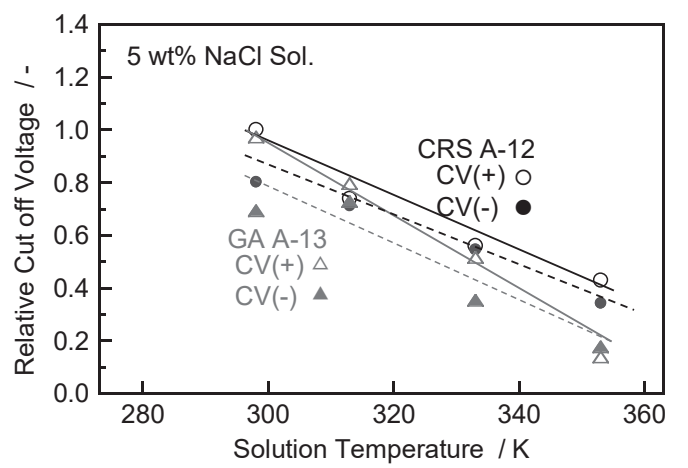

Fig. 6 Effects of solution temperature on the relative cut off voltage. 
は塗膜膨れの抵抗性(耐食性)の向上を意味するので，電 着塗装膜厚の増加とともに耐食性が向上することにな る. 本試験においても電着塗装膜厚の増加にともない遮 断電圧は増加した。 また, この遮断電圧は塗膜膨れサイ クル数と良く相関することが分かり，遮断電圧が塗膜膨 れに関する耐食性の評価法になり得ることが確かめられ た。

Fig. 7 中の膜厚 $10 \mu \mathrm{m}$ における塗膜膨れ発生サイクル 数(A-10, C-10, D-10)に注目する. 焼付条件が異なるこ とで塗膜膨れ発生サイクル数が変化していることが分か る. 電着塗装後の焼付条件によって膜質が変化したため と考えられる。 そこで, 膜特性の一つである電着樹脂の 架橋密度に対する複合サイクル試験での塗膜膨れ発生サ イクル数と遮断電圧の関係を Fig. 8 に示す. 電着樹脂の 架橋密度が高いと塗膜膨れ発生サイクル数および遮断電 圧は増加する傾向を示した。エポキシ系電着塗料では熱 エネルギーにより樹脂の架橋反応は進行する ${ }^{6)}$ ので, 焼 付温度が高く, 時間が長いほど架橋密度は高く, 塗膜膨 れに関する耐食性は向上すると考えられる.Fig. 8 中で 必ずしも全ての条件で遮断電圧データはないが, 塗膜膨

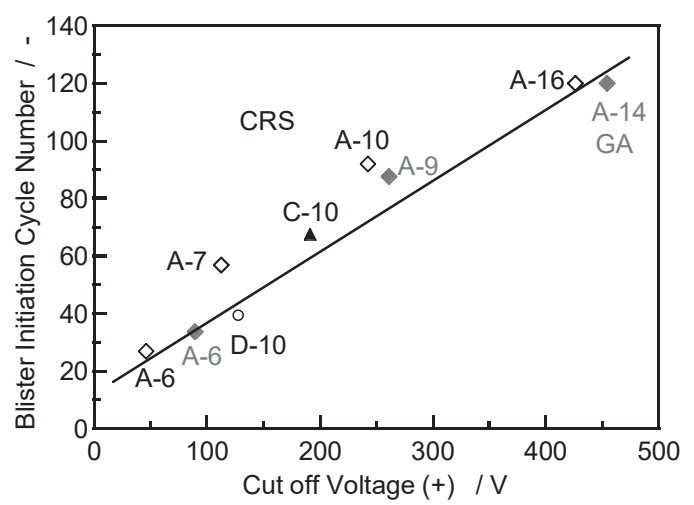

Fig. 7 Relation between blister initiation cycle number and cut off voltage $(+)$.
れ発生サイクル数と遮断電圧は比較的よく相関すること が分かる.

複合サイクル試験後の試験片表面を Fig. 9 に示す。図 中の数值は塗膜膨れ発生サイクル数を表している．電着 塗装膜が膨れているところで錆が発生している。これら の表面から, 塗膜膨れは全面的に起こるのではなく, 局 所的に発生することが分かる。したがって，本来電着塗 装膜は不均一な状態であると思われ，その表面の中で比 較的弱い部分に腐食因子が浸透して腐食が開始すると考 えられる.上記のように遮断電圧が塗膜膨れ発生サイク ル数とよく相関したことから，本報の高電圧印加法を用 いることで, 電着塗装膜厚や膜質と塗膜膨れに関する耐 食性を評価することができることが分かった．従来の複 合サイクル試験では試験開始から 3 力月後に塗膜膨れが 発生するのに対し, 高電圧印加試験法では遮断電圧の測 定により，5１0 分程度で耐食性評価が可能である.こ のことから, 塗装部の耐食性の迅速試験法として有効で あると考えられる．また，本法は工場など電磁波ノイズ の多い場所でも適用可能であることを確認している.

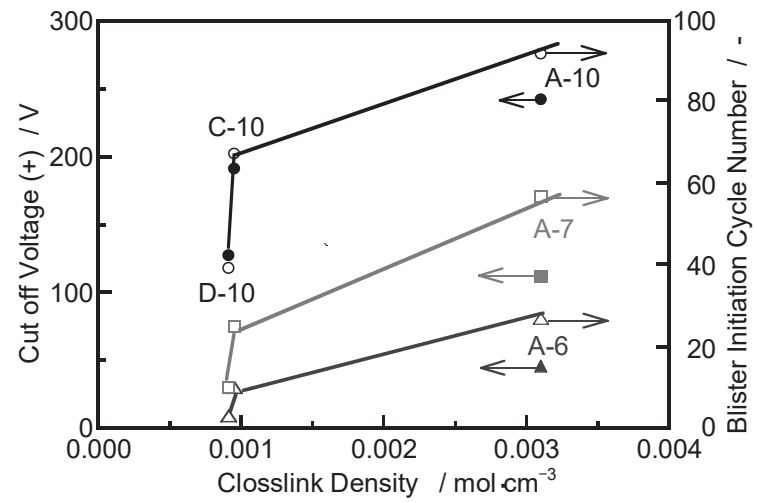

Fig. 8 Effect of crosslink density on cut off voltage $(+)$ and blister initiation cycle number.

\begin{tabular}{|c|c|c|c|c|}
\hline $\begin{array}{l}\text { Crosslink } \\
\text { density } \\
\left(\mathrm{mol} / \mathrm{cm}^{3}\right)\end{array}$ & ca. $6 \mu \mathrm{m}$ & ca. $7 \mu \mathrm{m}$ & ca. $10 \mu \mathrm{m}$ & ca. $15 \mu \mathrm{m}$ \\
\hline \multicolumn{5}{|l|}{0.00092} \\
\hline \multicolumn{5}{|l|}{0.00095} \\
\hline & 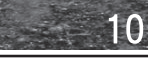 & 25 & 68 & $>120$ \\
\hline \multicolumn{5}{|l|}{0.0031} \\
\hline & 27 & 57 & 92 & $>120$ \\
\hline
\end{tabular}

Fig. 9 Surface appearances of electrodeposition coatings after blister initiation cycle tests. The numbers show the blister initiation cycle. 


\section{3 電着塗装膜のイオン透過}

溶液濃度の異なる $343 \mathrm{~K}$ の種々の溶液中から電着塗装 膜を通して透過するイオン量を電気伝導度の増加として 測定した例を Fig. 10 に示す。室温では $30 \mathrm{~min}$ という時 間範囲ではイオン透過による電気伝導度の上昇はほとん ど生じなかった。しかし， $343 \mathrm{~K}$ において $\mathrm{HCl}$ 溶液の電 気伝導度(濃度)の上昇とともにイオン交換水の電気伝導 度の上昇が顕著となった。一方, $\mathrm{NaCl}$ 溶液では僅かに 上昇したが， $\mathrm{NaOH}$ 溶液の濃度が高くなってもイオン交 換水の電気伝導度はほとんど上昇しなかった。このこと から, 今回用いた電着塗装膜は優先的な水素イオンの透 過性を示すことが分かった。電着塗装膜についてはカチ オン透過性を示唆した報告がある ${ }^{7)}$ が，水素イオンのイ オン半径が最も小さいこと, 電着塗装膜のガラス転移温 度が $373 \mathrm{~K}$ 付近にあること ${ }^{8)}$ から, 高温の溶液環境から の水素イオンの膜中の透過は起こり易いと見られる．試 験後の電着塗装膜の観察から, $\mathrm{HCl}$ 溶液を用いた場合に 電着塗装膜が膨潤し, 幾つものシワが現れた (Fig. 10 参 照).このシワは試験後もなくならなかったことから, 膜のイオン透過による劣化が示唆される.

$\mathrm{HCl}$ 溶液におけるイオン透過試験前後の電着塗装膜の FTIR 分析結果を Fig. 11 に示す. どちらの膜にも C-H, C-O-C 結合の存在を示す赤外光透過率の低下が見られ る。これらの結合はエポキシ樹脂の骨格と見られる。ま た，イオン透過試験後に $2200 〜 2800 \mathrm{~cm}^{-1}$ および 3000〜 $3600 \mathrm{~cm}^{-1}$ に透過率の低下が見られる。いずれも O-H 伸 縮振動に関連したスペクトルで, 電着塗装膜への水素イ オン透過による $\mathrm{OH}$ 基の増加または, 水分の吸着に起因

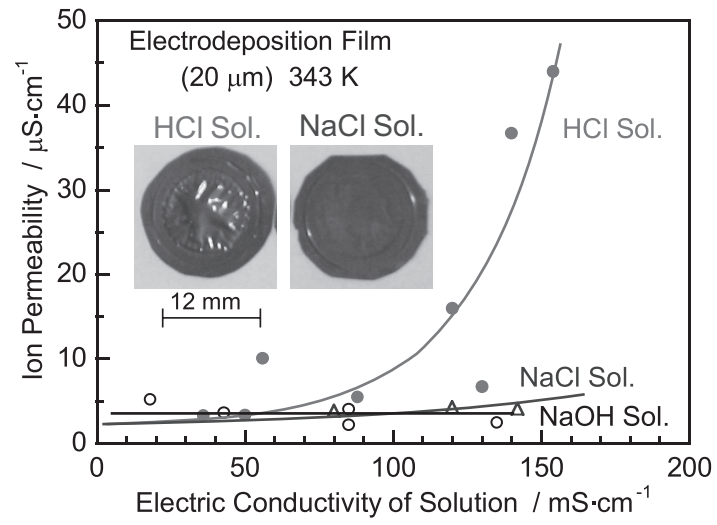

Fig. 10 Ion permeability of electrodeposition film in the various solutions.

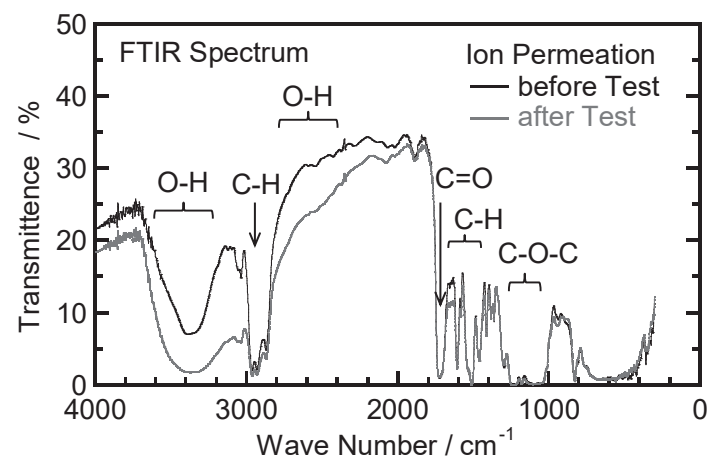

Fig. 11 FTIR spectrum of electrodeposition films before and after Ion permeability tests.
すると見られる．Fig. 6 において $353 \mathrm{~K}$ ，試験片をカソー ドとしたときの電圧印加で $\mathrm{GA}$ 試験片の遮断電圧がより 低くなったのは, 高い温度とカソードの電圧印加で電着 塗装膜への水と水素イオンの浸透が促進されたためと考 えられる。

\section{4 本試験法の妥当性}

一連の実験結果をもとに，本試験法の妥当性を考察す る。腐食環境にない電着塗装膜, 腐食環境および電圧印 加における電着塗装膜の構造モデルを Fig. 12 に示す. 電着塗装膜はエポキシ樹脂の架橋ネットワーク構造 $\left.{ }^{9)}, 10\right)$ をとっている(Fig. 12(a))。電着塗装表面が溶液に接す ると環境中のイオンや水分子が侵入し, $\mathrm{OH}$ 基の形成や 水の吸着により電着樹脂のネットワーク構造が広がるこ とでイオンが侵入しやすくなり，徐々に深さ方向に浸透 すると考えられる(Fig. 12(b))。したがって架橋構造が 密で, 電着塗装膜が厚いほど, 溶液の水分子はもとよ り，電着塗装表面からのイオンの侵入が抑えられ，腐食 抑制効果が高いと考えられる. 掃引速度 $1 \mathrm{~V} \cdot \mathrm{s}^{-1}$ の電圧 印加は電着塗装表面からの強制的なイオン侵入操作であ り (Fig. 12(c)), 遮断電圧は電着塗装膜内のイオン透過 に及ぼす電着塗装膜の厚さ，性質の影響を反映した結果 である。環境温度が高くなればネットワーク構造が膨 張・軟化しやすくなる. CRS と GA で遮断電圧の挙動が 極性や温度によって異なった事実は，化成処理層を形成 するリン酸塩結晶の形状 (Fig. 3 参照) や組成が異なるこ とで，その直上の部分の電着塗装膜の性質が変化したこ とに起因すると示唆される。本試験法で測定した遮断電 圧と複合サイクル試験における塗膜膨れ発生サイクル数 は良く相関した(Fig. 7 参照)。塗装部の腐食は水分子や イオンが電着塗装膜を透過して素地金属に到達ことで開 始すると考えられる。この腐食原理から考えても，高電 (a) Non Corrosive Environment

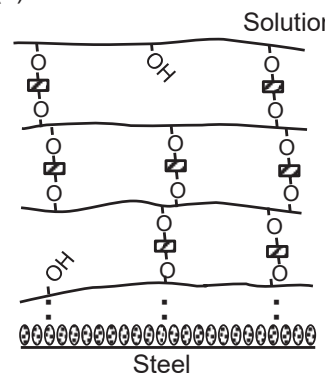

(c) Corrosive Environment with

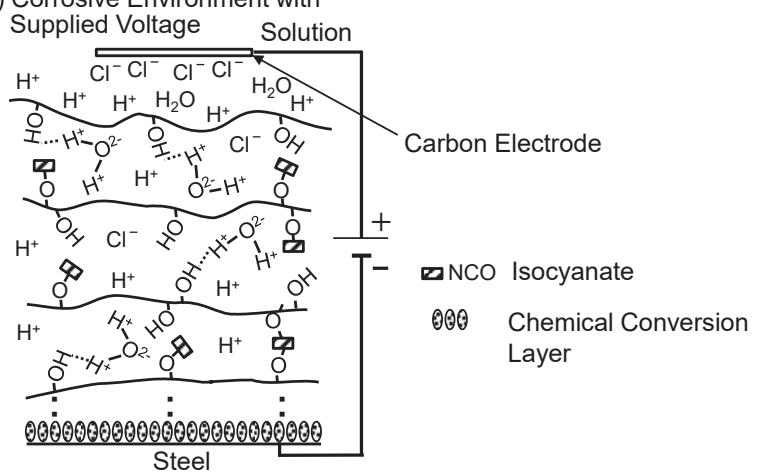

(b) Corrosive Environment

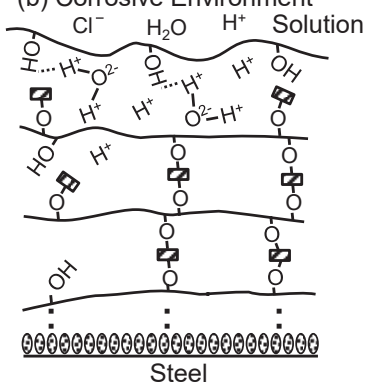

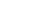

Fig. 12 Structural model of electrodeposition coating depending on environments. 
圧印加試験法は電着塗装部の塗膜膨れが生じるまでの期 間の迅速試験法として妥当であると見られる.

\section{4. 結言}

高電圧印加試験法を用いて電着塗装膜厚や焼付条件の 異なる非めっきおよび亜鉛めっき塗装鋼板を用いて，塗 膜膨れに関する耐食性を腐食因子遮断電圧として求め た。得られた結果は，以下の通りである。

1)電着塗装膜が厚いほど，また，樹脂の架橋密度が高い ほど，遮断電圧は高くなった。

2) CRS, GA 電着塗装膜の遮断電圧は試験液環境の温度 の上昇とともに低下した。

3) 遮断電圧は塗膜膨れ発生サイクル数と良く相関した。 塗膜膨れが生じるまでの期間(腐食抑制期間)を耐食性 評価の一つの指針にすると，高電圧印加法を用いて耐 食性を評価できることを示した。

4) 電着塗装膜のイオン透過性を調べたところ， $343 \mathrm{~K} に$ おいて水素イオンの透過性が水酸化物イオンや塩化物 イオンに比べて高いことが分かった.

5) 腐食環境の有無, 電圧印加における電着塗装膜の構造 モデルから, 塗膜膨れの耐食性試験法として本試験法 の妥当性を確認した。腐食環境下で電着塗装膜の表面
から環境中のイオンや水分子が侵入し，樑さ方向に浸 透する. 高電圧印加法により測定した遮断電圧は, 電 着塗装膜の表面からのイオン侵入・透過に及ぼす膜厚 や膜の性質を反映していると考えられる.

\section{参 考 文 献}

1) T. Tanaka, N. Takahashi, M. Tayu, Y. Takeichi and T. Abe, Journal of Japan Society of Civil Engineers, 69[3] pp.59-66 (2013).

2) K. Kajiyama, S. Fujita, K. Fujii and M.Sakai, Zairyo-toKankyo, 55, p.356(2006).

3) T. Kanbe and S. Suga, J. Surf. Finish. Soc. Jpn., 58[9] pp.526-537 (2007).

4) H. Fujiwara and S. Kanno, Journal of Japan Society of Civil Engineers, 35[537] pp.167-181(1996).

5) M. Asari, T. Tsuru and S. Haruyama, Boshoku Gijitsu (presently Zairyo-to-Kankyo), 36, p.134(1987).

6) T. Nakamichi, Jpn. Soc. Colour Mater., 65[8] pp.511-525 (1992).

7) Y. Sato, J. Surf. Finish. Soc. Jpn., 9[7] pp.272-275(1958).

8) S. Fujita and D. Mizuno, Corrosion Science, 49, pp.211-219 (2007).

9) N. Nikaido, Tetu-to-Hagane, 66[7] pp.953-963(1980).

10） R. Murakami, J. Surf. Finish. Soc. Jpn., 53[5] pp.288-292 (2002).
(Manuscript received August 20, 2018 ; in final form February 5, 2019)

\section{要旨}

電着塗装鋼板の耐食性の迅速試験法が本研究で提案された。電着塗装鋼板の耐食性評価時間を短縮する ために，本手法は線形掃引電圧 $1 \mathrm{~V} \cdot \mathrm{s}^{-1}$ で得られる腐食因子遮断電圧を数分間の操作で測定するものであ る. 異なる電着塗装膜厚および電着塗装後の異なる焼付条件のもとでカチオン電着塗装鋼板の遮断電圧が 測定された。結果として, 膜厚拝よび架橋密度の増加とともに遮断電圧は増加した。遮断電圧はサイクル 試験で得られた塗膜膨れ発生サイクル数と良く相関した。それ故に本手法の有効性が確認された。また, イオン透過性の試験および FTIR 分析は電着塗膜層へのイオンの侵入および水の吸着過程を示唆した. キーワード＼cjkstart耐食性評価，電着塗装鋼板，電気化学的測定 